Muhammed Fahmi Rabin H. Methodical approaches to participation of highly skilled track and field athletes in competitions. Theory and Methods of Physical education and sports. 2019; 1: 25-28 DOI:10.32652/ tmfvs.2019.1.25-28
Мухаммед Фахмі Рабін Х. Методичні підходи до участі у змаганнях легкоатлетів високої кваліфікації. Теорія і методика фрізичного виховання і спорту. 2019.1: 25-28 DOI:10.32652/tmfvs.2019.1.25-28

\title{
МЕТОДИЧНІ ПІДХОДИ ДО УЧАСТІ У ЗМАГАННЯХ ЛЕГКОАТЛЕТІВ ВИСОКОЇ КВАЛІФІКАЦІї
}

\section{Мухаммед Фахмі Рабін $X$}

Національний університет фізичного виховання і спорту України, Київ, Україна

Анотація. Стаття присвячена з'ясуванню підходів до участі у змаганнях легкоатлетів високої кваліфрікації протягом року як найважливішого чинника підвищення результатів у головних змаганнях року. Мета. 3'ясувати підходи до планування змагальної діяльності легкоатлетів високої кваліфрікації у процесі річної підготовки. Методи. Теоретичний аналіз і узагальнення науково-методичної літератури та інфоормації світової мережі Інтернет, законодавчих актів і програмних документів; аналіз і узагальнення календарів, протоколів, рейтингів змагань, результатів змагальної діяльності легкоатлетів високої кваліфікації. Результати. Проаналізовано участь у змаганнях легкоатлетів високої кваліфікації, призерів Ігор XXXI Олімпіади в Ріо-де-Жанейро і чемпіонату світу IAAФ, 2017 p. $(n=246)$.

Досвід передової спортивної практики свідчить про оптимізацію виступів у змаганнях спортсменів високої кваліфрікації протягом року, не зважаючи на розширення спортивного календаря та появу привабливих з комерційної точки зору турнірів. Підтверджено існування трьох основних методичних підходів до планування змагальної діяльності легкоатлетів протягом року. Для першого підходу характерна малоінтенсивна змагальна діяльність протягом року (до дев'яти змагань). Залежно від року проведення змагань його застосовує невелика кількість (5,0-10,2 \%) спортсменів. Другий - передбачає раціональний розподіл оптимальної кількості змагань (10-15) протягом року. Його використовує більшість переможців і призерів Ігор XXXI Олімпіади (74,8 \%), i чемпіонату світу (49,6 \%). Третій підхід орієнтує спортсмена на високоінтенсивну змагальну діяльність протягом року (понад 16 змагань) - 20,2-40,2 \% залежно від проведення головних змагань чотириріччя або року.

Ключові слова: змагання, легка атлетика, спортсмени високої кваліфрікації, Ігри Олімпіад, чемпіонати світу.

\section{Muhammed Fahmi Rabin $\mathrm{H}$. \\ METHODICAL APPROACHES TO PARTICIPATION OF HIGHLY SKILLED TRACK AND FIELD ATHLETES IN COMPETITIONS}

Abstract. The article deals with the elucidation of approaches to participation of highly skilled track and field athletes in competitions during the year as the most important factor in raising the results in the major competitions of the year. Objective. To elucidate approaches to planning the competitive activity of highly skilled track and field athletes in the process of annual training. Methods. Theoretical analysis and generalization of scientific-methodical literature and information of the Internet network, legislative acts and program documents; analysis and generalization of calendars, protocols, competitions' ratings, results of competitive activity of athletes of high qualification. Results. Participation of highly skilled track and field athletes, prize-winners of the XXXI Olympiad in Rio de Janeiro and the IAAF 2017 World Championship $(n=246)$ has been analyzed.

The experience of advanced sports practice indicates optimized performance in competitions of athletes of high qualification throughout the year, despite the expansion of sports calendar and the emergence of commercially attractive tournaments. The existence of three main methodical approaches to planning of competitive activity of athletes during the year has been confirmed. The first approach is characterized by low-intensity competitive activities throughout the year (up to nine competitions). Depending on the year of the competitions, it is used by a small number $(5,0-10,2 \%)$ of athletes. The second approach envisages rational distribution of the optimal number of competitions (10-15) during the year. It is used by most of the winners and prize-winners of the XXXI Olympiad (74.8\%), and the World Championship (49.6\%). The third approach directs the athlete to a high-intensity competitive activity throughout the year (over 16 competitions) - 20.2-40.2\% depending on the major competitions quadrennium or a year.

Keywords: competitions, track and field, highly skilled athletes, Olympic Games, World Championships.

Постановка проблеми. Рівень і розвиток спорту залежать від багатьох чинників соціального, політичного та економічного характеру, традицій підготовки, що склалися в певних країнах [6]. У сучасній системі підготовки спортсменів найважливішим ii компонентом є змагання, котрі розглядають як універсальний механізм управління удосконаленням спортивної майстерності атлетів. Вони визначають зміст тренувального процесу, виступають як необхідний інструмент контролю і значно впливають на розвиток виду спорту [6]. Iнтенсивні процеси професіоналізації і комерціалізації спорту призвели до розширення спортивних календарів у багатьох видах спорту, у тому числі 
й у легкій атлетиці [1, 3]. Протягом останніх десятиліть система змагань із легкої атлетики зазнала значних перетворень, які відбувалися під впливом цих стрімких процесів [3]. Ї̈̈ реформація триває і сьогодні.

Практично кожен рік відбуваються зміни у системі змагань з легкої атлетики, що звичайно впливає на тренувальну і змагальну діяльність спортсменів, але вони не завжди враховуються під час підготовки до змагань. Матеріальне стимулювання спортивної діяльності сприяло зацікавленості легкоатлетів у виступах у багатьох комерційних змаганнях [1, 3]. У 1990-х роках кількісні показники змагальної діяльності спортсменів високої кваліфікації протягом року досягли максимальних величин у різних видах змагань легкої атлетики. Так, легкоатлети, які спеціалізуються у бігу на короткі, середні і довгі дистанції, в легкоатлетичних стрибках і метаннях, брали участь у змаганнях протягом року від 49 до 65 разів $[4,5]$. Такий підхід часто приводив до перевтоми, виснаження, що позначалось на результативності змагальної діяльності, особливо в головних змаганнях року.

Нині ситуація змінилась, оскільки суттево зменшилась кількість змагань у системі підготовки легкоатлетів високої кваліфікації, про що свідчить досвід передової спортивної практики, проте ці перетворення не враховуються під час підготовки спортсменів високої кваліфікації, а рекомендації часто будуються на матеріалі 1980-х і 1990-х років. У зв'язку зі сказаним, проблема вивчення підходів для підвищення результативності змагальної діяльності безперечно є актуальною для розвитку системи спорту вищих досягнень, що потребує подальшого розгляду, обгрунтування на основі досягнень сучасної світової науки та практики, узагальнення даних Міжнародної асоціації легкоатлетичних федерацій (IAАФ), передового світового досвіду, розробок фахівців різних країн.

Мета дослідження - з'ясувати підходи до планування змагальної діяльності легкоатлетів високої кваліфікації у процесі річної підготовки.

Методи дослідження: теоретичний аналіз і узагальнення науково-методичної літератури та інформації світової мережі Інтернет, аналіз і узагальнення календарів, протоколів, рейтингів змагань, результатів змагальної діяльності легкоатлетів високої кваліфікації.

Результати дослідження та їх обговорення. У ході дослідження було проаналізовано виступи легкоатлетів високої кваліфікації, призерів Ігор XXXI Олімпіади в Ріо-де-Жанейро ( $\mathrm{n}=119)$ і чемпіонату світу ІААФ 2017 р. $(n=127)$, усього $\mathrm{n}=246$. Для з'ясування підходів до участі у змаганнях виявили загальну кількість змагань протягом року, динаміку спортивних результатів найсильніших легкоатлетів світу.

Аналіз динаміки спортивних результатів 246 спортсменів, які стали призерами Ігор XXXI Олімпіади в Ріо-де-Жанейро і чемпіонату світу
ІААФ 2017 р., свідчить про оптимальну загальну кількість змагань протягом року. У ході дослідження було отримано дані, що дозволили підтвердити існування трьох підходів до участі у змаганнях спортсменів високої кваліфікації з урахуванням специфіки виду спорту [6] та розширити наукові дані, отримані нами раніше [2] (рис. 1).

В основу кожного підходу було покладено участь спортсменів у змаганнях протягом року. Спортсменів умовно розподілили на три групи.

До першої групи увійшли призери Ігор Олімпіад і чемпіонатів світу, які переважно брали участь у незначній кількості змагань у процесі річної підготовки (до 10 разів). Для цього підходу характерна малоінтенсивна змагальна діяльність легкоатлетів протягом року. Його застосовує незначна кількість спортсменів: у рік проведення Ігор Олімпіад - $5 \%$, чемпіонатів світу ІААФ - $10 \%$ (див. рис. 1). У циклічних видах легкої атлетики 3 проявом витривалості (марафонський біг, спортивна ходьба) спортсмени брали участь у змаганнях на основній дистанції тільки один раз, про що свідчать дані, отримані з офіційних сайтів інформації ІААФ [7].

В ациклічних швидкісно-силових видах легкої атлетики (стрибки, метання) максимальні показники кількості змагань протягом року становили дев'ять разів, а у циклічних і змішаних швидкісносилових видах легкої атлетики (біг на короткі дистанції, бар'єрний біг) - вісім разів (див. рис. 1).

Представники другої групи виступали у змаганнях у оптимальній кількості змагань (10-15) протягом року. Другий підхід використовували більшість легкоатлетів (75 \% - у рік проведення Ігор Олімпіади і 50 \% - у рік проведення чемпіонату світу) (див. рис. 1). Оптимізація змагальної практики легкоатлетів високої кваліфікації сприяє показу найвищих спортивних результатів у головних змаганнях і дозволяе підвищити якісні характеристики змагальної діяльності в значущих комерційних турнірах. Залежно від виду легкої атлетики параметри участі у змаганнях коливаються в широкому діапазоні (див. рис. 1). Використовуючи цей підхід під час підготовки до Ігор Олімпіад, спортсмени у середньому виступали у змаганнях 10-11 разів, проте індивідуальні показники у більшості призерів коливалися у досить широкому діапазоні як у чоловіків, так і у жінок. У рамках цього підходу спортсмени після головних змагань можуть або припинити подальшу участь у змаганнях, або продовжувати виступати у незначній їх кількості, чи значну частину виступів перенести на терміни після завершення найважливіших змагань сезону.

Третій підхід передбачає високоінтенсивну змагальну діяльність протягом року (понад 16 змагань), що має в основному підготовчий характер, його застосовують $20 \%$ спортсменів у рік проведення Ігор Олімпіад і 40 \% - у рік проведення чемпіонатів світу. Переважно, це атле- 


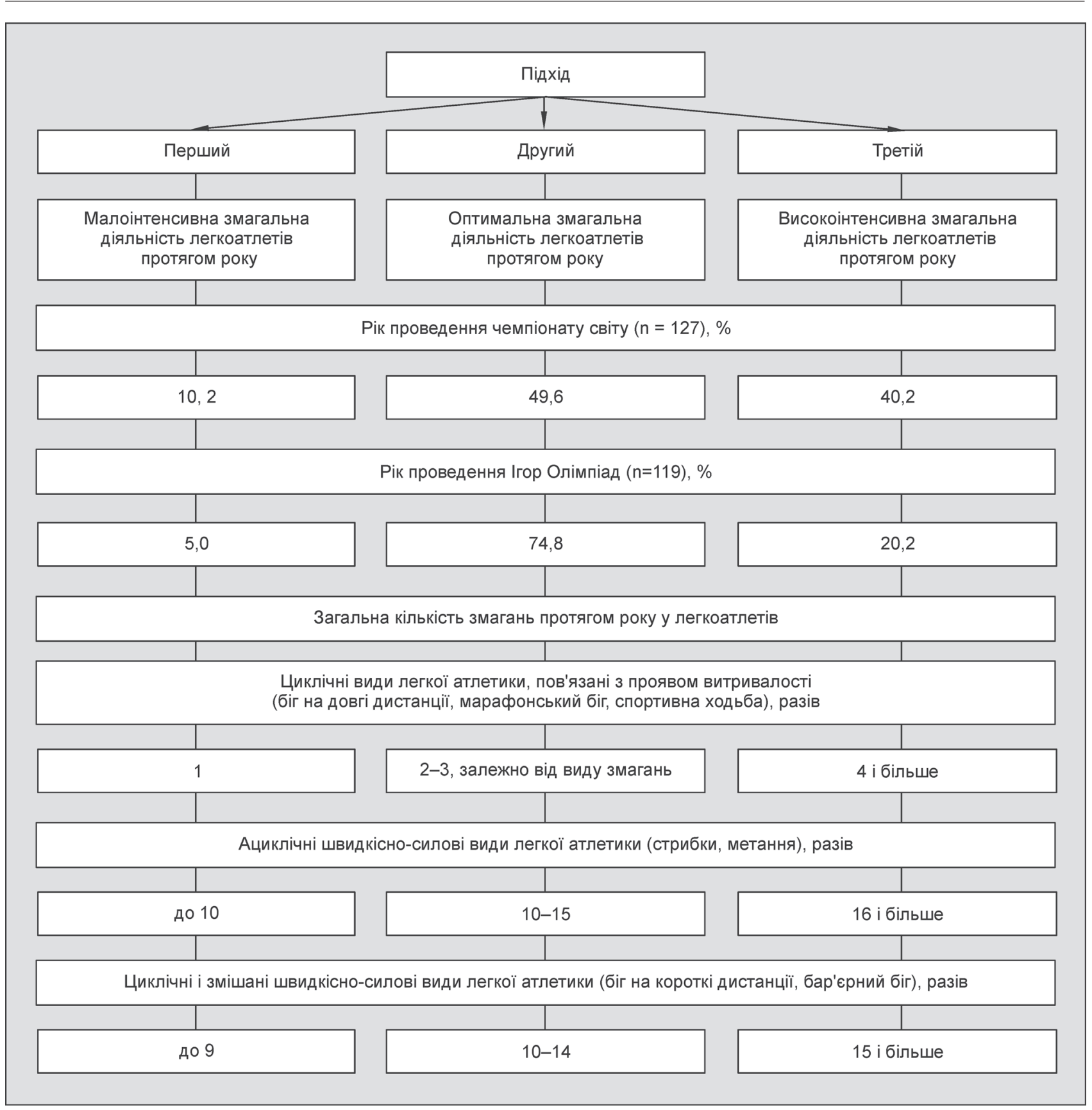

Рисунок 1 - Підходи до участі у змаганнях спортсменів високої кваліфікації

ти, які спеціалізуються у бігу на короткі дистанції та часто беруть участь у складі естафетних команд 4 × 100 м (наприклад, Де Грасс (Канада); Схіпперс (Нідерланди)), а також спортсмени, які спеціалізуються у багатоборствах. Для них виступ в окремих видах змагань, що входять до складу багатоборства, є важливим засобом не тільки підвищення рівня спеціальної підготовленості, а й удосконалення технічної майстерності (наприклад, Ітон (США); Тіам, (Бельгія); Тайсон Ітон, (Канада)) [2]. На Іграх Олімпіади з 121 спортсмена (чоловіки і жінки), які брали участь у змаганнях протягом року понад
30 разів, зафіксовано всього три випадки (Алі біг 100 з бар'єрами, Мартон - штовхання ядра і Тайсон Ітон - семиборство), що відповідає усього 2,5 \% загальної кількості спортсменів високої кваліфікації.

Необхідно відмітити підвищення ролі використання цього підходу у рік проведення чемпіонату світу, де показники його підвищуються на $20 \%$.

3 огляду на сказане, можна стверджувати, що існують три підходи до участі у змаганнях спортсменів високої кваліфікації [6] з урахуванням специфіки виду спорту. Доповнено наукові знання [2-4], що стосуються виступів легкоатлетів ви- 
сокої кваліфікації у змаганнях у рік проведення чемпіонату світу. Встановлено, що на відміну від існуючих підходів [4, 5], що були орієнтовані на виступи у максимальній кількості змагань (40-60 і більше) протягом року, атлети у сучасних умовах застосовують якісний підхід, тобто виступають в оптимальній кількості змагань протягом року. Як показує передовий досвід, такий підхід у різних видах легкої атлетики дозволяє підійти до головних змагань у стані найвищої готовності, знизити ризик перевтоми, виснаження легкоатлетів, сприяти тривалості спортивної кар'єри.

\section{Висновки:}

1. Досвід передової спортивної практики свідчить про виступи в оптимальній кількості (10-15) змагань протягом року переможців та призерів Ігор XXXI Олімпіади 2016 р. і чемпіонату світу IAAФ 2017 р., не зважаючи на розширення спортивного календаря та появу привабливих з комерційної точки зору турнірів. Встановлено, що світова легкоатлетична еліта протягом року виступає у змаганнях високого рівня з високими призовими фондами, що проводяться за скороченою програмою - в один день.
2. Виділено три основні методичні підходи до планування змагальної діяльності протягом року. Для першого підходу характерна малоінтенсивна змагальна діяльність, другий - передбачає раціональний розподіл оптимальної кількості змагань (10-15). Його використовували більшість легкоатлетів-переможців і призерів Ігор XXXI Олімпіади (75\%) і чемпіонату світу (50\%). Третій підхід орієнтує спортсмена на високоінтенсивну змагальну діяльність протягом року - 20-40 \% залежно від проведення головних змагань чотириріччя або року.

Перспективи подальших досліджень передбачають вивчення підходів до планування змагань з урахуванням етапу багаторічної підготовки, індивідуальних особливостей легкоатлетів шляхом узагальнення сучасних теоретичних напрацювань і практичного досвіду з підготовки спортсменів, виявлення недоліків та пошук можливих шляхів розробки моделей участі у змаганнях залежно від специфіки виду спорту і сучасної системи змагань, що в цілому дозволить їм підвищити результативність змагальної діяльності.

Конфлікт інтересів. Автор заявляє, що відсутній будь-який конфлікт інтересів.

\section{Література}

1. Борисова ОВ, Козлова ЕК. Профессионализация и коммерциализация в олимпийском спорте (на материале тенниса и легкой атлетики). Наука в олимп. спорте; 2017. 4: 61-71.

2. Козлова ЕК, Мухаммед Фахмі Рабин. Динамика результативности соревновательной деятельности сильнейших легкоатлетов мира в течение олимпийского года. Наука в олимп. спорте; 2016. 4: 23-34.

3. Козлова ОК. Категорії змагань та їх рейтингова характеристика в умовах професіоналізації легкої атлетики. Педагогіка, психологія та мед.-біол. пробл. фріз. виховання і спорту; 2009. 12: 90-34.

4. Колесов АИ, Ленц НА, Розумовский ЕА. Соревновательная деятельность и подготовка спортсменов высшей квалификации в различных природно-географических условиях. Москва: Физкультура и спорт, 2003. 292 с.

5. Матвеев ЛП. Основы общей теории спорта и системы подготовки спортсменов. Киев: Олимп. лит.; 1999.312 с.

6. Платонов ВН. Система подготовки спортсменов в олимпийском спорте. Общая теория и ее практические приложения. Киев: Олимп. лит.; 2015. 1: 680 с.

7. IAAF - International Association of Athletics Federations | iaaf.org https://www.iaaf.org/home

\section{Literature}

1. Borisova OV, Kozlova EK. Professionalization and commercialization in the Olympic sport (as exemplified by tennis and track and field). Nauka v olimpiyskom sporte; 2017. 4: 61-71.

2. Kozlova EK, Muhammed Fahmi Rabin. Dynamics of competitive activity efficiency of elite track and field athletes during the Olympic year. Nauka v olimpiyskom sporte; 2016. 4: 23-34.

3. Kozlova OK. Competition categories and their rating characteristics under conditions of track and field professionalization. Pedahohika, psykholohiia ta med.-biolohichni problem fizvykhovannia i sportu; 2009. 12: 90-34.

4. Kolesov Al, Lents NA, Rozumovsky EA. Competitive activity and elite athlete preparation under different natural and geographical conditions. Moscow: Fizkultura i sport, 2003. 292 p.

5. Matveyev LP. Bases of general sports theory and athlete preparation system. Kiev: Olimpiyskaya literatura; 1999.312 p.

6. Platonov VN. System of athletes' preparation in the Olympic sport. General theory and its practical applications. Kiev: Olimpiyskaya literatura; 2015. 1: $680 \mathrm{c}$.

7. IAAF - International Association of Athletics Federations | iaaf.org https://www.iaaf.org/home

Надійшла 18.02.2019

\section{Інформація про авторів}

Мухаммед Фахмі Рабін $X$

https:orcid.org/0000-0002-6087-4629

rabeenhashim@gmail.com
Information about the authors

Muhammed Fahmi Rabin $\mathrm{H}$ https:orcid.org/0000-0002-6087-4629 rabeenhashim@gmail.com

National University of Ukraine on Physical Education and Sport, 03150, Kyiv, Fizkul'ury str., 1
Національний університет фрізичного виховання і спорту України, 03150, Київ, вул. Фізкультури, 1 